\title{
SISTEM PENDUKUNG KEPUTUSAN PEMILIHAN ASISTEN TERBAIK DENGAN METODE TOPSIS DAN WP
}

\author{
Elyza Gustri Wahyuni ${ }^{1}$, Nadya Khairunnisa ${ }^{2}$ Fadhillah Abriyani $^{3}$, \\ Nurul Fatikah Muchlis ${ }^{4}$, Maria Ulfa ${ }^{5}$
}

\author{
Jurusan Teknik Informatika, Fakultas Teknologi Industri, Universitas Islam Indonesia, ${ }^{1,2,4,5)}$ \\ Jl. Kaliurang Km. 14,5, Sleman, Yogyakarta 55584 \\ E-Mail :elyza@uii.ac.id ${ }^{1)}$,14523289@students.uii.ac.id ${ }^{2}$, 14523288@students.uii.ac.id ${ }^{3)}$, \\ 14523293@students.uii.ac.id ${ }^{4)}$ 14523306@students.uii.ac.id ${ }^{5)}$
}

\begin{abstract}
The selection of the best assistants is an important aspect of performance management as it produces useful information for assistant administration decisions. Assistant administrative decisions is the selection of practicum managers, the determination of the amount of salary, and other decisions. The selection of the best assistants is not only for assistant administration decisions, but also useful as self-introspection and motivating to improve assistant performance. This research aims to apply decision support system with Technique for Order Preference by Similarity to Ideal Solution (TOPSIS) and Weighted Product (WP) method to a system that can perform task in choosing the best assistant. TOPSIS method is used for sub-criteria calculation and WP method for criteria calculation. Testing is done with Netbeans software and Java programming language. The criteria that become the best assistant assessment are discipline, attendance, and Assistant Performance Values (NKA). Each criteria has sub-criteria, that is for Discipline has a sub-criteria are tardiness and cash payment, for attendance has sub-criteria debriefing, meeting, and teaching, and for NKA has sub-criteria mastery of material, responses questions, ability to motivate, ability to manage time, and spirit assistant. Alternatives are selected from the laboratory assistants in the Integrated Laboratory of Informatics, are Yaya, Za, Syilvia, Kahfi, Oddy, and Ridwan. Testing is done by entering data assistant as much as six people. The system performs have faster calculation process than the manual calculation by producing the best assistant recommendation, namely Yaya with a value of 0.19734.
\end{abstract}

Keywords : Assistant, Selection, Decision Support System, TOPSIS, WP.

\section{PENDAHULUAN}

Asisten merupakan salah satu asset penting yang dimiliki Laboratorium Informatika Terpadu selama proses kegiatan akademik berlangsung. Dalam praktikum, asisten bertugas untuk memberikan teori maupun praktek secara langsung sesuai dengan kurikulum yang diterapkan. Selain mengajar, asisten bertugas untuk mengkoordinir segala administrasi yang berkaitan dengan praktikum yang bersangkutan, seperti presensi, maintenance system, mempersiapkan bahan ajar, dan melalukan pengujian (responsi) disetiap akhir semester.
Pemilihan asisten terbaik merupakan aspek yang cukup penting dalam manajemen kinerja, pemilihan asisten terbaik akan menghasilkan informasi yang valid dan berguna untuk keputusan administratif asisten seperti pemilihan manajer praktikum, penentuan jumlah vakasi yang diberikan, dan bermanfaat juga sebagai bahan instropeksi diri serta memotivasi untuk meningkatkan kinerja asisten. Pemilihan asisten terbaik yang digunakan saat ini pada laboratorium yang diteliti masih manual karena belum tersedianya sistem yang dapat merekomendasikan asisten terbaik dengan kriteria jumlah kehadiran, kedisiplinan asisten dan nilai kinerja asisten (NKA). 
Setiap kriteria yang ada memiliki subkriteria, yaitu untuk kedisiplinan memiliki sub - kriteria keterlambatan dan pembayaran uang kas, untuk kehadiran memiliki subkriteria pembekalan, rapat, dan mengajar, dan untuk NKA memiliki sub - kriteria penguasaan materi, tanggapan pertanyaan, kemamapuan, memotivasi, kemampuan mengatur waktu, dan semangat asisten. Untuk menyelesaikan masalah tersebut digunakan metode TOPSIS dan WP. Metode Technique for Order Preference by Similarity to Ideal Solution (TOPSIS) adalah metode yang didasarkan pada konsep dimana alternatif terpilih yang terbaik tidak hanya memiliki jarak terpendek dari solusi ideal positif, namun juga memiliki jarak terpanjang dari solusi ideal negatif. Alasan penggunaan metode TOPSIS ini karena menggunakan prinsip bahwa alternatif yang dipilih tidak hanya mempunyai jarak terpendek dari solusi ideal positif namun juga memiliki jarak terpanjang dari solusi ideal negatif, selain itu metode TOPSIS juga banyak digunakan untuk menyelesaikan masalah keputusan secara praktis serta konsepnya sederhana, mudah dipahami, komputasinya efisien dan memiliki kemampuan untuk mengukur kinerja relatif dari alternatif - alternatif keputusan kedalam bentuk matematis yang sederhana (Kusumadewi dkk., 2006).

Metode Weighted Product (WP) adalah metode yang menggunakan perkalian untuk menghubungkan rating atribut, dimana rating setiap atribut harus dipangkatkan dulu dengan bobot atribut yang bersangkutan, proses ini sama halnya dengan proses normalisasi (Kusumadewi dkk., 2006). Alasan penggunaan metode WP ini karena dapat mengevaluasi beberapa alternatif terhadap sekumpulan atribut atau kriteria, dimana setiap atribut saling tidak bergantung satu dengan yang lainnnya.
Di harapakan dengan menggunakan kedua metode tersebut dapat menyelesaikan masalah penentuan asisten terbaik yang terdapat pada Laboratorium Informatika Terpadu.

\section{METODE PENELITIAN}

Metodelogi penelitian merupakan proses atau cara ilmiah untuk mendapatkan data yang digunakan untuk keperluan penelitian. Menurut Nasir (1988 : 51), metode penelitian merupakan cara utama yang digunakan peneliti untuk mencapai tujuan dan menentukan jawaban atas masalah yang diajukan. Untuk memenuhi tujuan dan menentukan jawaban, maka diperlukan ruang lingkup penelitian penentuan asisten terbaik, yaitu sebagai berikut.

\section{a. Kerangka Kerja}

Kerangka kerja digunakan untuk menggambarkan langkah - langkah yang diterapkan dalam melakukan penelitian. Hal ini diterapkan agar penelitian ini dapat dilakukan secara terstruktur. Langkahlangkah yang digunakan mencakup mulai dari mengidentifikasi masalaah hingga implementasi sistem. Adapun pada jurnal ini diterapkan beberapa tahapan yang dilakukan terlihat pada gambar 1 .

\section{b. Lokasi Penelitian}

Lokasi penelitian yang diambil adalah Laboratorium Informatika Terpadu Universitas Islam Indonesia (UII). Obyek penelitian adalah asisten - asisten praktikum yang ada pada Praktikum Struktur Data.

\section{c. Waktu Penelitian}

Waktu penelitian menunjukkan data penelitian yang diambil yaitu data Praktikum Struktur Data Tahun Ajaran 2016/2017 Semester Genap. 


\section{d. Alat yang Digunakan}

Dalam melakukan penelitian dibutuhkan alat-alat yang dapat membantu proses penelitian, khususnya pada saat pengumpulan data. Pada proses pengumpulan data, alat - alat yang digunakan seperti berikut :

- $\quad$ Alat Tulis.

- Program Microsoft Excel.

- IDE Netbeans.

- Laptop.

- Wifi.

- Flashdisk.

\subsection{Pengumpulan Data}

Data yang diambil pada penelitian ini berupa data sekunder. Data sekunder yang diperoleh dari Divisi Presensi Praktikum Struktur Data. Data yang diambil berupa alternatif dan kriteria beserta sub kriterianya sebagai berikut :

- Alternatif.

- Yaya.

- Za.

- Syilfia.

- Kahfi.

- Oddy.

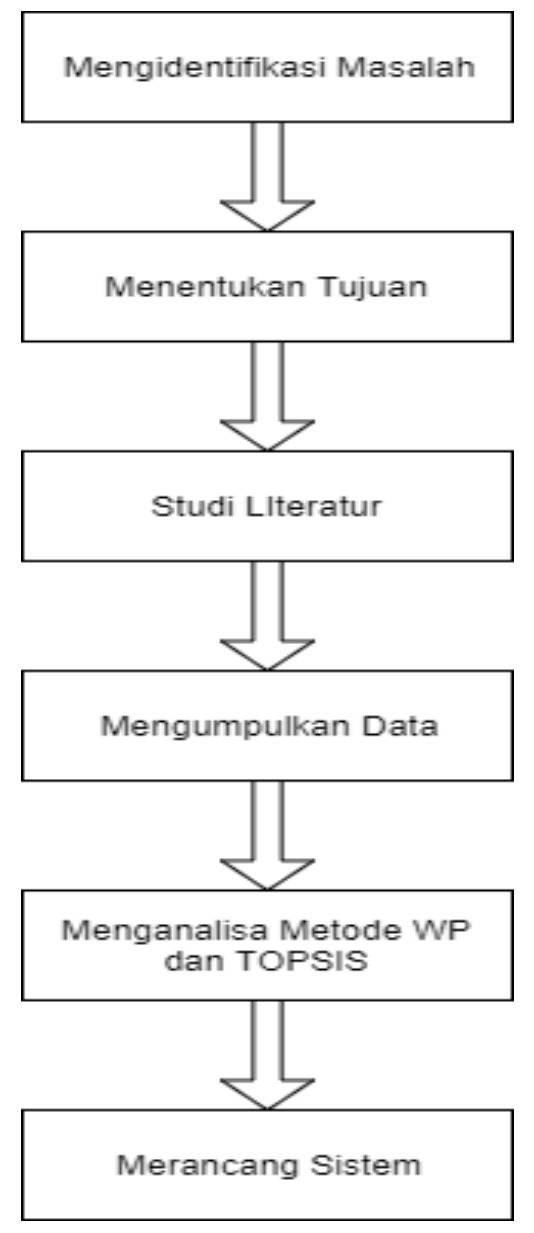

Gambar 1. Kerangka Kerja. 
Tabel 1. Matriks Bobot Awal

\begin{tabular}{|c|c|c|c|c|c|c|c|c|c|c|}
\hline \multirow{3}{*}{$\begin{array}{c}\text { KRITERIA / } \\
\text { ALTERNATIF }\end{array}$} & \multicolumn{2}{|c|}{ DISIPLIN } & \multicolumn{3}{|c|}{ KEHADIRAN } & \multicolumn{5}{|c|}{ NKA } \\
\hline & $\begin{array}{l}\text { Keterlambatan } \\
\text { (A) }\end{array}$ & $\begin{array}{c}\text { Pembayaran } \\
\text { Uang Kas } \\
\text { (B) }\end{array}$ & $\begin{array}{c}\text { Pembekalan } \\
\text { (C) }\end{array}$ & $\begin{array}{l}\text { Rapat } \\
\text { (D) }\end{array}$ & $\begin{array}{c}\text { Mengajar } \\
\text { (E) }\end{array}$ & $\begin{array}{c}\text { Penguasaan } \\
\text { Materi (F) }\end{array}$ & $\begin{array}{c}\text { Tanggapan } \\
\text { Pertanyaan } \\
\text { (G) }\end{array}$ & $\begin{array}{c}\text { Kemampuan } \\
\text { Memotivasi } \\
(\mathrm{H})\end{array}$ & $\begin{array}{c}\text { Kemampuan } \\
\text { Mengatur } \\
\text { Waktu (I) } \\
\end{array}$ & $\begin{array}{c}\text { Semangat } \\
\text { Asisten } \\
(\mathrm{J}) \\
\end{array}$ \\
\hline & 4 & 2 & 4 & 5 & 5 & 5 & 3 & 3 & 4 & 3 \\
\hline Yaya & 2 & 0 & 5 & 10 & 0.90 & 3.929 & 3.929 & 3.929 & 4.000 & 3.929 \\
\hline $\mathrm{Za}$ & 3 & 9 & 5 & 9 & 1.00 & 3.615 & 3.538 & 3.615 & 3.615 & 3.615 \\
\hline Syilvia & 2 & 9 & 5 & 9 & 1.00 & 3.435 & 3.391 & 3.435 & 3.435 & 3.391 \\
\hline Kahfi & 1 & 2 & 5 & 8 & 0.90 & 3.640 & 3.640 & 3.560 & 3.640 & 3.680 \\
\hline Oddy & 1 & 7 & 5 & 8 & 0.75 & 3.455 & 3.636 & 3.273 & 3.636 & 3.545 \\
\hline Ridwan & 4 & 7 & 5 & 9 & 0.95 & 3.727 & 3.773 & 3.682 & 3.727 & 3.727 \\
\hline TOTAL & 13 & 34 & 30 & 53 & 5.50 & 21.80 & 22.06 & 21.37 & 22.05 & 21.89 \\
\hline
\end{tabular}

Tabel 2. Matriks Bobot WP

\section{W}

- Ridwan.

- Kriteria dan Sub - kriteria.

- Kedisiplinan.

- Keterlambatan.

- Pembayaran Uang Kas.

- Kehadiran.

- Pembekalan.

- Rapat.

- Mengajar.

- NKA.

- Penguasaan Materi.

- Tanggapan Pertanyaan.

- Kemampuan Memotivasi

- Kemampuan Mengatur Waktu.

- Semangat Asisten.

\subsection{Rekapitulasi Data}

Data yang diambil pada penelitian ini berupa data sekunder. Data - data yang diperoleh dari Divisi Presensi direkap dengan program Microsoft Excel. Dimana data yang telah direkap dianalisis dan dievaluasi untuk dijadikan sebagai alternatif dan kriteria beserta sub - kriterianya. Alternatif yang digunakan adalah sebagian asisten yang ada pada Praktikum Struktur
Data, yaitu Yaya, Za, Syilfia, Kahfi, Oddy, dan Ridwan. Kriteria terdiri dari kehadiran, kedisiplinan asisten dan nilai kinerja asisten (NKA). Setiap kriteria yang ada memiliki sub - kriteria, yaitu untuk kedisiplinan memiliki sub - kriteria keterlambatan dan pembayaran uang kas, untuk kehadiran memiliki sub - kriteria pembekalan, rapat, dan mengajar, dan untuk NKA memiliki sub - kriteria penguasaan materi, tanggapan pertanyaan, kemamapuan, memotivasi, kemampuan mengatur waktu, dan semangat asisten.

\subsection{Analisis Data}

Data yang telah direkap kemudian dianalisis, adapun tahapan - tahapan pengerjaan analisis data adalah sebagai berikut :

- Menentukan nilai dari setiap subkriteria.

- Menentukan tingkat kepentingan dari kriteria dan sub - kriteria yang akan dijadikan bobot. 
Tabel 3. Matriks Ternormalisasi

\begin{tabular}{llllllllll}
\hline \multicolumn{10}{c}{ NORMALISASI R } \\
\hline 0.338062 & 0.000000 & 0.408248 & 0.460776 & 0.399114 & 0.440983 & 0.435823 & 0.449516 & 0.443820 & 0.439264 \\
0.507093 & 0.553912 & 0.408248 & 0.414698 & 0.443460 & 0.405740 & 0.409534 & 0.404782 & 0.401102 & 0.404159 \\
0.338062 & 0.553912 & 0.408248 & 0.414698 & 0.443460 & 0.385538 & 0.376146 & 0.387963 & 0.381130 & 0.379116 \\
0.169031 & 0.123091 & 0.408248 & 0.368621 & 0.399114 & 0.408546 & 0.403766 & 0.407299 & 0.403876 & 0.411426 \\
0.169031 & 0.430820 & 0.408248 & 0.368621 & 0.332595 & 0.387782 & 0.403322 & 0.374463 & 0.403432 & 0.396333 \\
0.676123 & 0.430820 & 0.408248 & 0.414698 & 0.421287 & 0.418311 & 0.418519 & 0.421257 & 0.413529 & 0.416681 \\
\hline
\end{tabular}

Tabel 4. Matriks Ternormalisasi Terbobot

\begin{tabular}{llllllllll}
\hline \multicolumn{8}{c}{ NORMALISASI Y } \\
\hline 1.352247 & 0.000000 & 1.632993 & 2.303878 & 1.995570 & 2.204916 & 1.307470 & 1.348547 & 1.775280 & 1.317793 \\
2.028370 & 1.107823 & 1.632993 & 2.073491 & 2.217300 & 2.078702 & 1.228602 & 1.214345 & 1.604409 & 1.212477 \\
1.352247 & 1.107823 & 1.632993 & 2.073491 & 2.217300 & 1.927688 & 1.128437 & 1.163890 & 1.524522 & 1.137347 \\
0.676123 & 0.246183 & 1.632993 & 1.843103 & 1.995570 & 2.042732 & 1.211298 & 1.221896 & 1.615505 & 1.234278 \\
0.676123 & 0.861640 & 1.632993 & 1.843103 & 1.662975 & 1.938912 & 1.209967 & 1.123389 & 1.613730 & 1.188999 \\
2.704494 & 0.861640 & 1.632993 & 2.073491 & 2.106435 & 2.091555 & 1.255557 & 1.263770 & 1.654117 & 1.250042 \\
\hline
\end{tabular}

Tabel 5. Matriks Solusi Ideal Positif dan Negatif

\begin{tabular}{lllllllllll}
\hline \multicolumn{1}{c}{ NORMALISASI Y1 } \\
\hline 0.676123 & 1.107823 & 1.632993 & 2.303878 & 2.217300 & 2.204916 & 1.307470 & 1.348547 & 1.775280 & 1.317793 \\
\hline \multicolumn{8}{c}{ NORMALISASI Y1 } \\
\hline 2.704494 & 0.000000 & 1.632993 & 1.843103 & 1.662975 & 1.927688 & 1.128437 & 1.123389 & 1.524522 & 1.137347 \\
\hline
\end{tabular}

Tabel 1 menunjukkan matriks bobot awal yang akan digunakan pada proses TOPSIS. Pada baris yang berwarna ungu, menunjukkan bobot TOPSIS yang digunakan pada perhitungan metode TOPSIS tersebut. Sedangkan pada tabel 2 menunjukkan matriks bobot untuk metode WP. Namun, bobot awal yang digunakan sebenarnya secara berurutan kedisiplinan, kehadiraan, NKA adalah sebagai berikut 3, 5, dan 4. Untuk memudahkan dalam perhitungan maka, bobot awal tersebut dinormalisasi sehingga dihasilkan bobot WP seperti pada tabel 3 .

\section{HASIL DAN PEMBAHASAN}

Penentuan asisten laboratorium terbaik pada sistem pendukung keputusan dengan metode WP dan TOPSIS menggunakan bahasa Java. Perhitungan sub-kriteria merupakan perhitungan dengan metode
TOPSIS. Pada metode TOPSIS, nilai bobot untuk sub - kriteria keterlambatan 4, pembayaran uang kas 2, pembekalan 4 , rapat 5, mengajar 5, penguasaan materi 5, tanggapan pertanyaan 3, kemampuaan memotivasi 3 , kemampuan mengatur waktu 4, dan semangat asisten 3. Sedangkan untuk perhitungan kriteria dan menentukan nilai preferensi akhir menggunakan metode WP. Pada metode WP, nilai bobot dari kriteria kedisplinan 0.250, kehadiran 0.417, dan NKA 0.333. Nilai bobot kriteria tersebut telah dinormalisasi dari nilai sebenarnya, yaitu 3, 5, dan 4 .

Langkah perhitungan pertama yang dilakukan adalah perhitungan sub - kriteria dengan metode TOPSIS. Adapun tahapan tahapan yang dilakukan pada metode TOPSIS yaitu : 
Tabel 6. Matriks Jarak Alternatif dengan Solusi Ideal

\begin{tabular}{cccc}
\hline & \multicolumn{3}{c}{ NILAI D+ } \\
& DISIPLIN & KEHADIRAN & NKA \\
\hline D1+ & 1.297850 & 0.221730 & 0.000000 \\
D2 & 1.352247 & 0.230388 & 0.309144 \\
D3+ & 0.676123 & 0.230388 & 0.488310 \\
D4+ & 0.861640 & 0.511350 & 0.289993 \\
D5+ & 0.246183 & 0.720826 & 0.416711 \\
D6 & 2.043255 & 0.255675 & 0.204947 \\
\hline \multicolumn{3}{|}{} \\
\hline D1- & NILAI D- & NKA \\
D2- & 1.352247 & 0.568273 & 0.505020 \\
D3- & 1.297850 & 0.600296 & 0.201337 \\
D4- & 1.748097 & 0.600296 & 0.040501 \\
D5- & 2.043255 & 0.332595 & 0.217893 \\
D6- & 2.203794 & 0.000000 & 0.131903 \\
& 0.861640 & 0.499735 & 0.303667 \\
\hline
\end{tabular}

Tabel 7. Matriks Nilai Preferensi

\begin{tabular}{cccc} 
& \multicolumn{3}{c}{ NILAI V } \\
& DISIPLIN & KEHADIRAN & NKA \\
\hline V1 & 0.510263 & 0.719330 & 1.000000 \\
V2 & 0.489737 & 0.722653 & 0.394406 \\
V3 & 0.721097 & 0.722653 & 0.076589 \\
V4 & 0.703383 & 0.394096 & 0.429021 \\
V5 & 0.899516 & 0.000000 & 0.240433 \\
V6 & 0.296617 & 0.661542 & 0.597048 \\
\hline
\end{tabular}

Tabel 8. Matriks Bobot Awal

\begin{tabular}{cccc}
\hline KRITERIA / & DISIPILN & KEHADIRAN & NKA \\
ALTERNATIF & $\mathbf{3}$ & $\mathbf{5}$ & $\mathbf{4}$ \\
\hline Yaya & 0.490 & 0.719 & 1.000 \\
Za & 0.510 & 0.723 & 0.395 \\
Syilvia & 0.279 & 0.723 & 0.077 \\
Kahfi & 0.297 & 0.394 & 0.429 \\
Oddy & 0.100 & 0.000 & 0.241 \\
Ridwan & 0.703 & 0.662 & 0.598 \\
\hline Total & $\mathbf{2 . 3 7 9}$ & $\mathbf{3 . 2 2 0}$ & $\mathbf{2 . 7 4 0}$ \\
\hline
\end{tabular}

a. Menentukan matriks keputusan yang ternormalisasi.

b. Perhitungan matriks keputusan ternormalisasi tersebut didapatkan dari perhitungan rating kinerja setiap alternatif pada setiap kriteria, disebut dengan normalisasi R.

c. Matriks keputusan ternormalisasi yang didapatkan dapat terlihat pada tabel 3.
Setelah menemukan nilai matriks ternormalisasi R. Tahapan selanjutnya, menentukan matriks keputusan yang ternormalisasi terbobot. Perhitungan matriks ternormalisasi terbobot yaitu sama dengan menentukan matriks ternormalisasi sebelumnya, namun yang membedakan yaitu pada perkalian nilai bobotnya. 
Tabel 9. Matriks Vektor S

\begin{tabular}{ll}
\hline & NILAI S \\
& \\
\hline S1 & 2.716918 \\
S2 & 2.443318 \\
S3 & 2.219595 \\
S4 & 2.348429 \\
S5 & 1.595693 \\
S6 & 2.421880 \\
\hline
\end{tabular}

Tabel 10. Matriks Vektor V

\begin{tabular}{ll} 
& NILAI V \\
& \\
\hline V1 & 0.197654 \\
V2 & 0.177750 \\
V3 & 0.161474 \\
V4 & 0.170847 \\
V5 & 0.116086 \\
V6 & 0.176190 \\
\hline
\end{tabular}

Adapun hasil yang didapatkan untuk matriks ternormalisasi terbobot dapat terlihat pada tabel 4. Langkah selanjutnya yakni menentukan matriks solusi ideal positif dan matriks solusi ideal negatif. Matriks nilai tersebut didapatkan dari rating bobot ternormalisasi nilai sebelumnya. Sehingga, hasil dari solusi ideal positif dan negatif dapat dilihat pada tabel 5 .

Menentukan jarak antara nilai setiap alternatif dengan matriks solusi ideal positif dan matriks solusi ideal negatif. Jarak positif didapatkan dari nilai alternatif dengan solusi ideal positif. Sedangkan jarak negatif didapatkan dari nilai alternatif dengan solusi ideal negatif. Tabel 6 diatas menunjukkan hasil jarak nilai setiap alternatif.

Menentukan nilai preferensi untuk setiap alternatif. Hasil yang didapatkan dapat dilihat pada tabel 7. Tahapan ini merupakan tahapan terakhir pada metode TOPSIS. Nilai preferensi dari setiap alternatif yang didapatkan tersebut dijadikan bobot awal dari setiap kriteria yang ada. Dan kemudian, dijadikan sebagai bobot pada perhitungan metode WP.
Setelah diperoleh nilai preferensi setiap kriteria yang ada pada metode TOPSIS, tahapan selanjutnya adalah perhitungan kriteria dengan metode WP. Tahapantahapan yang dilakukan pada metode WP yaitu bobot awal WP ditentukan dari hasil akhir pada metode TOPSIS. Adapun bobot awal WP dapat terlihat pada tabel 8 .

Menentukan vektor S. Nilai vektor S didapatkan dari penjumlahan seluruh setiap nilai kriteria dari setiap alternatif yang telah dipangkatkan dengan nilai bobot WP yang telah ternormalisasi. Sehingga didapatkan hasil pada tabel 9 .

Setelah didapatkan nilai vektor $\mathrm{S}$, kemudian dilakukan perhitungan vektor $\mathrm{V}$ yang akan digunakan untuk perangkingan. Perhitungan vektor $\mathrm{V}$ didapatkan dari pembagian dari setiap nilai $S$ dengan penjumlahan seluruh vektor $\mathrm{S}$ yang ada. Sehingga, didapatkan hasil seperti tabel 10.

Berdasarkan hasil nilai vektor $\mathrm{V}$ yang didapatkan, nilai terbesar dimiliki oleh V1. Sehingga alternatif Yaya merupakan alternatif yang terpilih sebagai alternatif terbaik. Dengan kata lain, Yaya terpilih sebagai asisten laboratorium terbaik. 


\section{KESIMPULAN}

Berdasarkan perhitungan dengan metode WP dan TOPSIS yang digunakan dalam pemilihan asisten terbaik, dengan nilai bobot untuk sub - kriteria keterlambatan 4, pembayaran uang kas 2 , pembekalan 4 , rapat 5, mengajar 5, penguasaan materi 5, tanggapan pertanyaan 3, kemampuaan memotivasi 3, kemampuan mengatur waktu 4, dan semangat asisten 3 . Sedangkan bobot dari kriteria kedisplinan 0.250 , kehadiran 0.417, dan NKA 0.333. Sistem penentuan asisten terbaik merekomendasikan Yaya sebagai alternatif terbaik.

\section{DAFTAR PUSTAKA}

Firdaus, I., H.,Abdillah G., dan Renaldi, F., 2016. Sistem Pendukung Keputusan Penentuan Karyawan Terbaik Menggunakan Metode AHP dan TOPSIS, Jurnal Nasional Teknologi Informasi dan Komunikasi, Universitas Jendral Ahmad Yani, pp. 440-445.

Kusumadewi, S. et al., 2006. Fuzzy MultiAttribute Decision Making (FUZZY MADM). Graha Ilmu. Yogyakarta.

Nazir., 1988. Metode Penelitian. Ghalia Indonesia. Jakarta. 